\title{
Increasing Economic Welfare of Church Congregation: A Concept of Empowerment
}

\author{
Tongam Sihol Nababan \\ Department of Development Economics, Faculty of Economics \\ University of HKBP Nommensen \\ Email: ts_nababan@yahoo.com, tsnababan@gmail.com
}

Received: October 4, 2016; Accepted: January 18, 2016; Published: March 2, 2017

Permalink/DOI: http://dx.doi.org/10.17977/um002v9i12017p113

\begin{abstract}
In our community, many structural problems unresolved well, especially in social and economic life. Seeing this reality, the Church needs to have a sensitivity and a strong commitment to encourage cooperation of some parties to empower people, especially its congregation. Congregation of the Church, especially the poor need to be raised and empowered to pursue their own welfare through economic business. One manifestation of the Church's task is to empower the community-based and to revitalize its role more focused on optimizing the institution of community economy. For that, it is important to use the Model of Empowerment of Congregation-Based Community Economic in form of business partnership. The success of congregation economic empowerment lies in the motivation and orientation of the actors themselves, where the Church is expected to seriously fight.
\end{abstract}

Keywords: Church, Congregation, Community-Based Economic, Business Partnership, Empowerment.

JEL Classification: D60, I31

\section{INTRODUCTION}

God blesses the world with the amazing natural resources. Nonetheless, we continue seeing that the social welfare is still far from expectation. There are several socio-economic indicators to be concerned, i.e: poverty, corruption, and low human development, etc. There are some structural issues which unresolved, especially income inequality among communities, gaps of development among regions, high unemployment, culture of permissive law violations, corruption, and varieties of other social disorder. Facing this reality, some efforts have been made by the government and private institution to address these problems. But those efforts have not shown optimal results because it is constrained by a number of factors, such as the application of market mechanism which is not pro-people, public policy not in favor of small communities, globalization, and cultural gap.

Amid this unfavorable life, the government should keep on ensuring that the common welfare remains a primary goal of national life and fought through public policies. The Public policy should be the main device of the government to pursue the prosperity. However, the reality shows that many people prefer to take advantage of public policy positions as well as to enrich themselves or groups. Not a few among the board of legislative, executive, and judicial continue to deny the mandate received from the people to fight for the common welfare. They 
prefer the struggle for salary increases and benefits for private life rather than the interests of the people represented.

Seeing the social-economic reality, the other institution outside the government, such as non-government organizations (NGOs), churches, non-profit organizations, etc can involve and participate to overcome these problems. These parties are expected to assist the government in reducing the so called problems by empowering their potentiality among the communities. One of the parties is an institution of Church. It is expected that a church should be able to show its role among its community or congregation.

Church needs to have a sensitivity and a strong commitment to encouraging cooperation among the elements of the government, market forces, and community institutions to empower people, especially the small and marginalized communities. Supposedly, the Church is called to involve actively in the process of socio-economic empowerment of society with the vision of building a self-supporting Church. The self-supporting congregation is a Church community who is able to think, plan and realize the dreams, hopes, and ideals of the next life with effort and strength of their own for the sake of a better life and more equitable. The negligence of Church during this time to address the above matters cannot be continued in a preoccupation. It is time for the Church with its congregation to realize the need for reform in mentality, work ethic, ethical and moral economy which should be required to optimize the role of the church as an institution and a personal of Christian.

In this paper, I wish to describe and to stress how an institution of Church should take a part, empower it to help its community or congregation to gain the welfare. I also offer a model of Empowerment of Congregation-Based Community Economics as a conceptual framework which can be applied to achieve it through the programs of the Church.

\section{LITERATURE REVIEW}

\section{Economic Welfare in Perspective of Church}

Many people question: Should the Church help to think about the economic problems faced by the congregation? Does not Church only focus on matters of faith? In the context of the Church role in society, Fernandez (2005) as cited by Wilhelmus (2010) confirmed that the concept of the Churches as the people of God always encourage us to more actively integrate ourselves with the life experience of mankind and more open to matters of political, economic, health, education, housing, social justice, welfare and people's living environment. Thus when people covered by situations of injustice, human rights violations, and oppression, the Church needs to be performed to help and to educate the society in order to define themselves as agents of a reformer who able to free themselves from the situation faced by their own power. Refinding the human freedom is the duty of the Church means the Church in various fields of human life must be active to liberate and to bring the human being into a prosperous life (Lumbantobing, 2007).

One element of making Church congregation be prosperous is an economic activity, such as to create a business or enterprise involving the congregation. But the economic context of the church is rarely raised as an interesting topic for discussion in among the congregation. It is more interesting 
to discuss other topics, such as culture, law, politics, and so forth. Whereas there are so many economic values that can be learned and developed in the service programs. Sometimes talking about the profit, the interest of money, the project tender, wealth and other matters concerning the economic and business are abstinence. The Church could not do business, should not be the pursuit of profit. Why is that? During this time, there is an incorrect understanding of the principle of economic or business that is inherent in the minds of the people that "with the smallest sacrifices (capital) will gain maximum profit" so that if this understanding is applied in the environment of the Church to be something wrong, contrary to Christian faith, because the principle can allow or justify all of the ways to obtain the maximum profit.

The understanding of the economic principle (business) is incorrect and allegedly misinterpreted or understood as incomplete model from "freedom of competion" popularized by Adam Smith in his book An Inquiry into the Nature and Causes of the Wealth of Nations (1776) ${ }^{(1)}$ (always called as The Wealth of Nations) as a trigger for the emergence of "capitalism". In a review of The Wealth of Nations performed by Skousen (2005) stated that, indeed, the ideal society aspired by Adam Smith is a society filled by the value of kindness, generosity, and civil laws prohibiting the practice of economic (business) to be fraudulent and unfair. Smith wanted to integrate the economy with the moral behavior ${ }^{(2)}$. More pointedly, Smith stated that one of the functions of the most economical and significant of religious belief is to provide a strong incentive to retain its moral which can assist and support civil society, namely: honesty, virtue, refrain from violence and greed, and so forth (Nath, 2007).

But long before it, The Bible has been providing some educational and economic principles for us, such as found in the scriptures: Proverbs 3: 9-10; Proverbs 11: 25; Matthew 25: 14-30; 2 Corinthians 9: 6-8; Philippians 4: 19. Even in the Bible, there are more than 2,350 verses on how to manage money and assets (Dayton, 2005).

The social-economic decay that we are suffering today is the result of those who patterned think to act and to rebel against the Lord in the business and economic life. If the Christians and the Church want to contribute significantly to the economic reforms that are oriented correctly, then we must start thinking biblically, such as:

(1) Assume that the economic wealth is not his or her own, but belongs to God deposited.

(2) Do not be egoistic to save economic wealth for yourself, but God wanted it also to be a blessing to others.

(3) Do not make economic wealth as the mainstay of life and wealth does not preclude a relationship with God.

(4) In an effort to accumulate economic wealth does not make a person deviate from the faith.

Indeed, the Church must confess frankly that economic issues can not be separated from the failures of Church, theologians, and Christians in obeying the truth of God's word. Church has failed to give a clear and true teaching of the implications of biblical truth into the world of economy. Church has failed to maintain the principles of business ethic and moral of economy, both to its 
congregation and talk to outside as an insight and attitude of Christians about the economy around the world.

(1) In the original script of An Inquiry into the Nature and Causes of the Wealth of Nations (1776), reprinted in 1976 (p. 687) says: "Every man, as long as he does not violate the laws of justice, is left perfectly free to pursue his own interest in his own way, and to bring both his industry and capital into competition with those of any other man, or order of men "(West, 1990).

(2) The aim of Adam Smith to write The Wealth of Nations (1776) was to break the conventional view held by the mercantilism, which dominated the trade and political power at the time. He wanted to replace it with a system that generates wealth and real growth to bring the United Kingdom and the whole world towards the improvement of the of ordinary people.

According to Hidayat (2006), just the opposite, the Church itself tends to make a fatal mistake to understand the message of salvation from God in monetary symbols. Many people think that "the advanced or modern Church" is simply a vibrant church in service by utilizing the techniques, methods and advanced tools as developed in the marketing techniques. Most theories about progress and church growth use the quantitative measures and not the behavior of repentance to all aspects of economic life. Therefore, as suggested by Mangeloja (2003), the Church also may focus on particular institutions that can realize and improve the economic performance of the congregation, not only on the conviction and faith.

\section{The Role of Christians and the Church}

The social-economic decay that we are suffering today is the result of those who patterned think to act and to rebel against the Lord in the business and economic life. If the Christians and the Church want to contribute significantly to the economic reforms that are oriented correctly, then we must start thinking biblically, such as:

(1) Assume that the economic wealth is not his or her own, but belongs to God deposited.

(2) Do not be egoistic to save economic wealth for yourself, but God wanted it also to be a blessing to others.

(3) Do not make economic wealth as the mainstay of life and wealth does not preclude a relationship with God.

(4) In an effort to accumulate economic wealth does not make a person deviate from the faith.

Indeed, the Church must confess frankly that economic issues can not be separated from the failures of Church, theologians, and Christians in obeying the truth of God's word. Church has failed to give a clear and true teaching of the implications of biblical truth into the world of economy. Church has failed to maintain the principles of business ethic and moral of economy, both to its congregation and talk to outside as an insight and attitude of Christians about the economy around the world. According to Hidayat (2006), just the opposite, the Church itself tends to make a fatal mistake to understand the message of salvation from God in monetary symbols. Many people think that "the advanced or modern Church" is simply a vibrant churche in service by utilizing the techniques, methods and advanced tools as developed in the marketing techniques. Most theories about progress and church growth use the quantitative measures and not the behavior of repentance to all aspects of economic life. Therefore, as suggested 
by Mangeloja (2003), the Church also may focus on particular institutions that can realize and improve the economic performance of the congregation, not only on the conviction and faith.

Wayan Mastra as cited by Veen (2009) emphasized the importance of developing the economy of the congregation with the concept of "Stomach Theology" which states that an empty stomach has no ears. It means, if the congregations still struggle for the needs of everyday life, it will be difficult for them to have the Word of God. Mastra believes that Christians should not live in poverty but live as "capitalist" in the sense of always doubling of capital and ability as parables of Jesus about the multiplication of talent (Matthew 25: 14 30). Mastra responded that the business activities of the church are spiritual. Because all thoughts of business activities of the Church are the spiritual thoughts and then all the business activities of the Church is based on the attempt of surrendering ourselves and to establish a good relationship with God. A good relationship with God will cause a person's life to be awarded various forms of blessing.

In practice, many efforts undertaken by the church community to create economic welfare of its congregation. Some churches in the world operate a business and they consider no longer as a more economic activity but as an evangelical mission to help the congregation (Jong, 2008). Mulford (2009) suggested that economic activity or business carried out by the Church must be a "transformation engine" in the form of a "channel of blessing" for those who believe and who do not believe in Jesus Christ. Even in operations, activities of businesses owned by the Church in the United States of America has become a "holding company", as practiced by the First Assembly of God Church, LifeBridge Christian Church, Friendship Missionary Baptist Church, and the Evangelical Christian Credit Union (ECCU) California. They fund and operate private schools, shelters, food services (catering), credit cards, loans for small businesses, housing, shops and offices, commercial aviation business, and sports arenas.

There are also many Catholic and Protestant churches that have set up cooperatives People, schools and colleges, printing, and so forth, all of which are dedicated to the welfare of their congregation. But is it managed as holding company? ${ }^{(3)}$ For future development, it is also possible that in order to boost economic missions of the Church to improve the life of the congregation, a model of Incorporated ${ }^{(4)}$ will be required. This model can act and operate as a mediator, facilitator, and consolidate the potency and economic resources of the Church. But, like any form of management, all forms of economic activities of the Church should be geared towards the efforts to improve the life of the congregation.

\section{METHOD}

This paper is written based on a literature review and conceptual analysis. Here, the literature review and conceptual analysis are intended to identify key aspects in building a model of empowerment of church congregation. 


\section{RESULT AND DISCUSSION}

\section{The Role of Church to Achieve Economic Welfare of Congregation}

The welfare of congregation is one of the most important principles in a way of thinking and acting of the Church. Knowingly and intentionally, the church must seek the implementation of the principle, because the Church is convinced that the welfare cannot be released to an automatic process as to which occur in the market mechanism. Thus, the Church considers that the economic life which only depends on the will of the large-scale employers or businessmen and government initiatives is not a wise way to achieve the welfare.

The congregation of the Church, especially the poor need to be raised and empowered to seek their welfare by generating small scale business based on community, also called "community-based economics or community economics" (5). The support of large-scale businesses and government is certainly needed. However, with or without the support of the poor and the weak must still rise to empower themselves. For that the Church can perform two-way movement to guide the way.

(3) A holding company is a company that owns other companies' outstanding stock. The term usually refers to a company that does not produce goods or services itself; rather, its purpose is to own shares of other companies to form a corporate group. Holding companies allow the reduction of risk for the owners and can allow the ownership and control of a number of different companies.

(4) An Incorporated is the umbrella of management to strengthen the network both vertical and horizontal. In the concept of incorporated, small and medium businesses scale which have a comparative advantage, united in a holding, which is to be a catalyst to build networking of production, distribution, and marketing on a global level.

(5) Community-based economics or community economics is an economic system that encourages local substitution. It is most similar to the lifeways of those practicing voluntary simplicity, including traditional and modern eco-village communities. It is also a subject in urban economics, related to moral purchasing and local purchasing.

forward, namely:

(1) The effort of empowering the potency and energy of the poor and weak with the involvement of intellectuals to search the governance of economic life which really realize the common welfare.

(2) Critical encouragement to the government and large-scale economic actors to engage more actively in realizing the common welfare, with special attention to those who are poor and weak, without making them even more dependent on others.

In addition to the above movement, active efforts of the Church should be focused on empowering the potency and energy of social-economic of the poor and the weak themselves. Some fields that can be empowered such as microfinance institution, cooperative, home industry, service, etc. They need to be expanded and fully supported. Of course, this empowerment requires other movements to urge the various of public policies in the field of economy, increasingly put the poor and the weak to be the main actors in the economic life of their own country. Therefore, the Church must really give primary attention to the little people through the real operational programs and capable of inducing the productive economic activities at the level of the Church congregation and at the same time able to foster the entrepreneurial spirit.

One manifestation of the Church task to empower community-based economic is to revitalize its role which more focused on optimizing the economic institution, particularly in terms of financing. Several empirical studies conducted 
by Asy'arie (2001); Helmsing (2003) showed that the common problems faced by the actors of community economic (for example, small and medium enterprises and cooperatives) are the lack of access to sources of financing and capital, limited to mastery of technology and information, limited to market access, and limited to organization and management. The Church is expected to play a role here. With the capability of this community economic institutions, the economic enterprises of congregation can access sources of financing from private and government organizations, even the sources of financing from overseas.

\section{Model of Empowerment}

According to Syahza (2001); Pike et al. (2015), one of the effective ways to achieve the role of good economic institutional is to build business partnership. Based on observations in community, found several factors which can support the empowerment of the congregation-based community economic, i.e: (1) the role of higher education (university or college), (2) the businessmen, (3) credit institutions, (4) economic business of congregation (farmers, entrepreneurs), (5) the government agencies, (6) Church-owned cooperatives. These factors can be operated in a series of work which show the interaction of business partnership as presented in Figure 1.

The model of empowerment in Figure 1 can be explained as follows: Higher Education (universities or college) plays a role through a research and development institute, or research center. The role of Higher Education has three of dimensional strengths, namely: (1) to explore the potency of the Church and the congregation, (2) to understand the potency of community environment, and (3) to give the formulation of recommendation from a blend of first and second dimension to the group of business partnership. As an independent institute, Higher Education also acts as supervisory institute to economic activities of the Church.

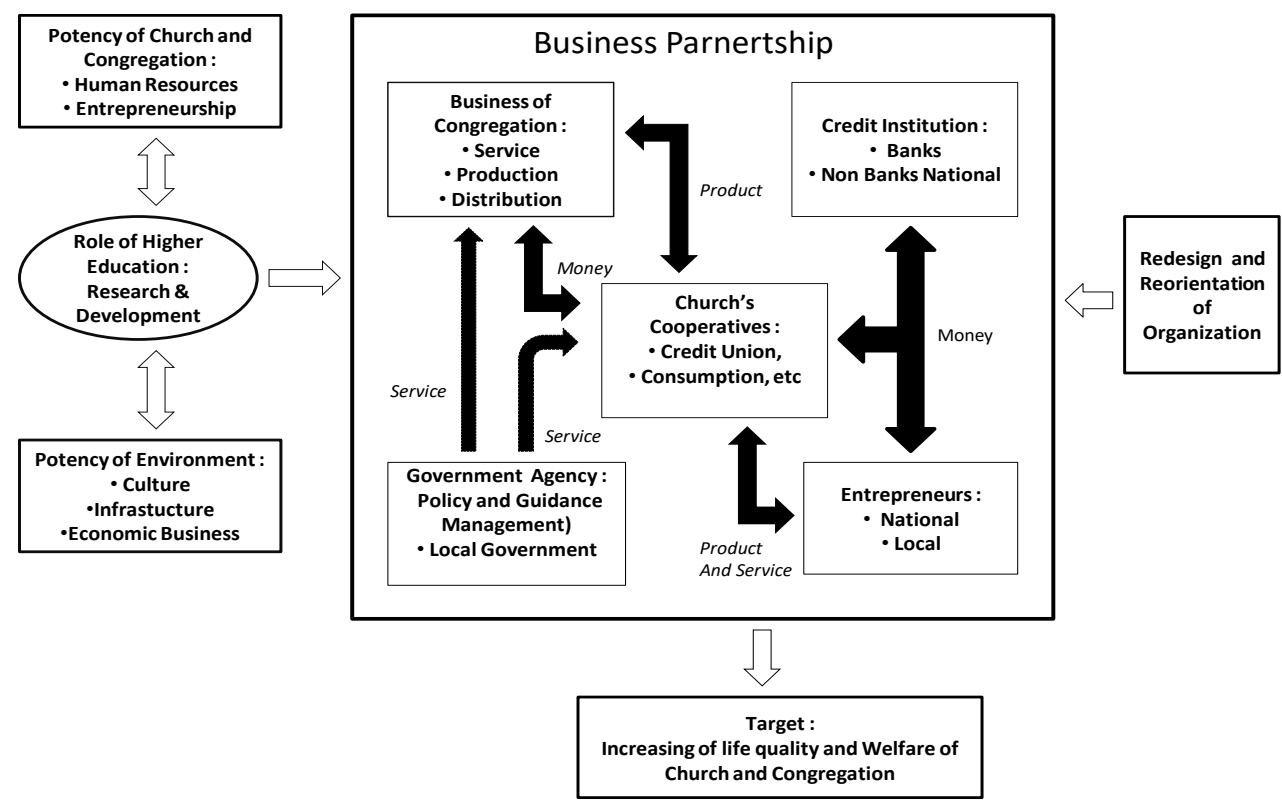

Figure 1. Model of Empowerment of Congregation-Based Community Economic 
In the box of business partnership there are five groups that mutually interact and as an integral unity in the economic activities of the Church. To develop the economic activities of the Church, it needs to form the cooperatives operated by the Church. In this case, the cooperatives also act as instruments of market information concerning with market opportunities, price conditions, and the purchasing power of the market. The business units of congregation conduct the business activities based on the agreement with the Church's cooperatives. Their business activities will be accompanied by a team of the expert appointed by the cooperatives.

The involvement of government agencies in the model of economic empowerment of congregation is limited to policy makers and guidance management. The policy is regarding the rules and regulations of mutual benefit. While the guidance management can be given to cooperatives and business of congregation. The government agencies may be to provide guidance management to these groups by using professionals from outside, either from universities or from other professional institutions. In this empowerment model, credit institutions only deal directly with cooperatives and entrepreneurs. The credit is distributed through the Church's cooperative to the business of the congregation. The cooperatives propose loans for working capital which will be used by business of congregation and for the cooperatives themselves. While credit to entrepreneurs could be in the form of business development (supermarkets, shops, export, technology, etc). Here, the entrepreneurs refer to the owner of capital and as traders (brokers, distributors, retailers). As the owners of capital, they establish cooperation with the Church's cooperatives in the provision of production infrastructures. The entrepreneurs can also provide market information through cooperatives, whether regarding the purchasing power of the market, market opportunities, and so forth.

Another attempt can be done is to empower organizations through redesign and re-orientation of the organization (Kasali, 2007). The most suitable redesign of organization for the Church is organic design or dynamic re-design, not mechanistic design or moving like a machine. Because the Church lives dynamically and grows in line with social changes around them. Besides, this organic re-design can provide an opportunity for creativity and innovation in the Church. Re-orientation is intended to foster positive attitudes in the renewal of such openness to new things, to foster values of discipline and work ethic and creativity. To achieve this, it is good for the Church and the congregation learns from the experience of Muhammadiyah. In an effort to optimize the service to its communities, Muhammadiyah forms some assemblies in various fields (e.g: assembly of tarjih and tajdid, assemblies of sermons and preaching, assemblies of endowment and infaq sadhoqah, the panel of primary and secondary education, the board of health and welfare, the assembly of economic and entrepreneurship, assemblies of community empowerment, and assemblies of cadre education).

\section{CONCLUSION}

The empowerment of congregation through the ministry of the Church to improve performance, productivity, and quality of the congregation can only be realized through a change. In that effort, the principle of the welfare of the congregation needs to be used as an approximation. That is, the principle of the 
welfare of congregation can be used as a principle to set the agenda in planning, implementing, and evaluating programs to empower the economic potency of the congregation. We are all willing to get involved to make changes to the process that had led to the symptoms of inequality of economic welfare of the congregation. For that, economic empowerment of congregation should take priority in the program of the Church, so that the economic business of the Church. Using the model of business partnership, the economic empowerment of the congregation should be able to cope and reduce the constraints and obstacles faced during this time. Therefore, the success of congregation economic empowerment lies in the motivation and orientation of the actors themselves. Finally, we are expected to develop a way of thinking and a new way of acting with sensitivity and concern for others, so that the common life and the welfare can be achieved.

\section{REFERENCES}

Asy'arie, M. (2001). Keluar dari Krisis Multi Dimensi. Yogyakarta: Lembaga Studi Filsafat Islam.

Dayton, H. (2005). Pelajaran Keuangan Menurut Alkitab. Jakarta: Crown Financial Ministries Indonesia. Retrieved from http://www.crown.or.id/ produk.htm.

Helmsing, A. B. (2003). Local economic development: New generations of actors, policies and instruments for Africa. Public Administration \& Development, 23(1), 67.

Hidayat, P. (2006). Perspektif Kristen Tentang Ekonomi, Edisi 075/VI/2006/. Retrieved from http://www.sabda.org/e-reformed/

Jong, E. D. (2008). Religious Value and Economic Growth: A Review and Assesment of Recent Studies. NiCE Working Paper 08-111. Institute for Management Research, Radboud University of Nijmegen.

Kasali, R. (2007). Re-code Your change DNA: Membebaskan BelengguBelenggu Untuk Meraih Keberanian dan Keberhasilan Dalam Pembaharuan. Jakarta: Penerbit Gramedia.

Lumbantobing, D. (2007). Teologi di Pasar Bebas. Pematang Siantar: Penerbit LSAPA (Lembaga Studi Agama, Pembangunan dan Budaya).

Mangeloja, E. (2003). Application of Economic Concepts on Religious Behavior, School of Business and Economics, University of Jyväskylä, Finland, P.O.Box 35, FIN-40014. Retrieved from http://129.3.20.41/eps/othr /papers/0310/0310003.pdf

Mulford, J. E. (2009). The Church and Business: Working together in God's plan of Redemption, VOICE for All Nations. Retrieved from http://kingdomentrepreneur.

Nath, S. (2007). Religion \& Economic Growth and Development. Indira Gandhi Institute of Development Research, MPRA Paper No. 8181. Retrieved from http://mpra.ub.uni-muenchen.de/8181/)

Pike, A., Marlow, D., McCharthy, A., O’Brien, P., \& Tomaney, J. (2015). Local Institutions and Local Economic Development: The Local Enterprise Partnerships in England, 2010-. Cambridge Journal of Regions, Economy and Society, 8(2), 185-204. 
Skousen, M. (2005). The Making of Modern Economics, The lives and Ideas of the Great Thinkers Terjemahan Indonesia: "Sang Maestro Teori-teori Ekonomi Modern", Alih Bahasa T. W. B. Santoso. Jakarta: Penerbit Prenada Media.

Syahza, A. (2001). Studi Sosial Ekonomi dan Pemberdayaan Masyarakat di Propinsi Riau. PPKPEM Universitas Riau, Pekanbaru.

Veen, M. G. M. (2009). Teologi Kewirausahaan, Konsep dan Praktik Bisnis Gereja Kristen Protestan di Bali. Salatiga: Taman Pustaka Kristen dan Centre for Business Ethics and Profesionalism ,Universitas Kristen Duta Wacana.

West, E. G. (1990). Adam Smith and Modern Economics, From Market Behaviour to Public Choice. Vermont, USA: Edward Elgar Publishing Ltd.

Wilhelmus, O. R. (2010). Pemberdayaan Sosial Ekonomi Sebagai Suatu Model Evangelisasi Dalam Konteks Indonesia. STKIP Widya Yuwana Madiun (Seminar Paper). 